\title{
STRESS INDUCED STRAUB TAIL ELEVATION FURTHER BEHAVIORAL EVIDENCE IN RATS FOR THE INVOLVEMENT OF ENDORPHINS IN STRESS
}

\author{
R.J. KATZ \\ Mental Health Research Institute, Department of Prychiatry, Uninomity of Michigan \\ Medical Center, Ann Arbor, MI 48109 (U.S.A.)
}

(Received April 2nd, 1979)

(Revised version received May 7th, 1979)

(Accepted May 8th, 1979)

\section{SUMMARY}

Adult male Sprague-Dawley rats briefly immersed in cold water and forced to swim showed Straub tail elevation, a typical sign of opiate stimulation, upon removal. The presence of Straub tail was a function of degree of immersion and was reversed by naloxone. This suggests the Straub tail response may be a novel behavioral index of stress-indured endorphin release.

Stressful manipulations of many sorts have been stown to affect behavior through the release of endogenous opioid peptides. A kil et al. [2] reported the induction of andigesia after shock, which correlated with increased opiate-like acttvity and which was reversible in part by naloxone. Cold vater stres produces a similar syndrome (e.g., ref. 3). Other forms of stress inciuding centrifugal rotation and the injection oi hypertonic saline solution may also induce related analgesic states although these may have primarily nonnarcotic mediation [4].

In addition to anaigesia, a further typical sign of opiate stimulation in rodents is the Straub tail response. This response consists of tail extension, rigidity and elevation subequent to a variety of opiate treatments $[1,5,6]$. The response is opiate specific, naloxone reversible and subject to modification by manipulation of biogenic amines [1].

To further characterize stress as a ivehavioral ayndrome with a possible relation to endorphins, stress-incluced Straub tail response in the rat was examined in the present experiment.

Twenty-four adult male Sprague-Dawley ats (Charles River, Portage, MI) $80-130$ days of age and weighing an average of $405 \mathrm{~g}$ (ranige $=300-520)$ the start of texting were individually maintained with food (Teklad $4.0 \%$ fat rodent diet) and tap water continuously available. Normal $12 \mathrm{~h} / 12 \mathrm{~h}$ 
light/dark cycles (lights on $=07: 00-19: 00 \mathrm{~h}$ ) were maintained by automatically programmed artificial lighting.

Subjects were habituared to handling through daily exposures during the week preceding testing. This was necessary to assure control procedures would not themselves be stresful.

The strese procedure consisted of placing the rat individually in a $25 \times 37$ $x 38 \mathrm{~cm}$ plastic container $75 \%$ filled with an ice-water mixture maintained at $4^{\circ} \mathrm{C}$. Ice was added as required to maintain temperature. The rat, was removed after $0.5,1.6$ or $5.0 \mathrm{~min}$ of exposure and placed upon a tabie for cbservation. The rat's hindquarters were placed over the edge of the table without support. Light manual prescure was applied to the back to maintain the animal in an immobile position. Straub tail was scored upon a presence/ absence scale with criteria for presence being tail rigidity and extension directed either in an upwards direction or level with the body (note that the tail extendi:d past the testing table and was not supported). If the tail was pointing in a down wards direction Straub tail was considered to be absent. Straub tail is generally scored based upon visual observations and these criteria are in accord with typically employed criteria (e.g., ref. 6). Rats were tested on two occasions separated by 7 days each and order of treatr rpnts was counterbalanced. Using the rating criteria and procedures of the present experiments we have not found tolerance to the stress induced effect in rats matched for age and strain (unpublished). Three swim durations were ex. amined with respect to control (no swim): these were $0.5,1.6$ and $5.0 \mathrm{~min}$. In addition three dose of the opiate blocker nalox one were administered to the 5 min stress group to evaluate the effects of receptor blockade. Nalox one $\mathrm{HCl}$ (Fndo Laboratories) was administered intraperitoneally $1 \mathrm{ml} / \mathrm{kg}$ in doses of $0.2, \therefore .0$ and $20.0 \mathrm{mg} / \mathrm{kg}$ approx. $15 \mathrm{~min}$ prior to testing. Hesults are prisenied as percentage positive scores per condition. In all cases 6 rats were used for each experimental cell.

Struub tail wes induced by swimming in ice water. This was a naloxone revers ble effect. Both of these effects were essentially monotonic, as may be seen in Table I. The increase in tail elevation is significant for both 1.6 and 5.0 min compared to control (by the Fisher exact test; $P<0.05$ ). In addition both 8.0 and $20.0 \mathrm{mg} / \mathrm{kg}$ of naloxone reduce the normal elevation $(P<0.05$ Fishe: exact test).

Striub tail elevation in the stresed rat may be a functional narker for the normal activity of endogenous opioid systems. Since activation of endor.jhins by strass has ieen defined through limited behavioral means this is a pistentially useful extension of its behavional characterization. These result: suggest stress-induced changes are not restricted to analgesiz, but may be $m=$ astired through another typically used index of opiate stimulation.

While no direct measurements of endogenous opioid activity were taken, nalox one reversal supports the present findings as opiate specific. The highest dose $(20 \mathrm{mg} / \mathrm{kg})$ is generally regarded as non-peific but the intermediate dose has been used as a specific opiate blocker. The present findings 


\section{TABLE I}

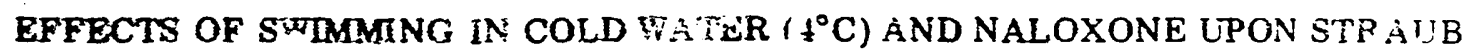
TAIL ELEVATION IN TIEE $\&$

A. Stroub tail produced dy cata waser...ng in the rat

Time swirnming $\%$ of rats with positive response ${ }^{a}$ (min)

$\begin{array}{lr}0 & 0 \\ 0.5 & 0 \\ 1.5 & 33 \\ 5.0 & 100\end{array}$

B. The an tagonism of the Straub tail by intraperitoneal naloxone

Dase naloxone ${ }^{b} \quad$ \%o of rats with positive response

$(\mathrm{mg} / \mathrm{kg})$

\begin{tabular}{rr}
0 & 100 \\
0.2 & 100 \\
2.0 & 16 \\
20.0 & 0 \\
\hline
\end{tabular}

"In all cases $\%$ positive represents th. percentage of rats of a given group of six showing either rigid extended or elevated tail ، opponse as further defined in the text.

${ }^{b}$ Dose administered $15 \mathrm{~min}$ prior to test.

therefore may represent true opiate mediated effects which are n't denen dent upon non-specific sedation.

\section{ACKNOWLEDYBMENTS}

We gratefully acknowledge the generous donation of drug by Findo Laboratories and the editorial assistance of Elizabeth Romkema.

\section{REFERENCES}

1 Aceto, M.D., Mckean, D.B. and Pearl, J., Effects of opiates and opiate antagonisis on the Straub tail reaction in mice, Brit. J. Pharmacol, 36 (1969) 225-239.

2 Akil, H., Midden, d., Patrick, R.C. and Barchax, J.D., Stress induced increase in endogenous op te peptides: concurrent analgesia and its partial reverual by naloxione: In H.W. Kosterlitz (Ed.), Opiates and Endogenous Opiate Peptides, Elsevier, Amster. dam, 1976, pp. 63-70.

3 Bodnar, R.J., Kelly, D.D., Bpiargia, A., Ehrenberg, C. and Glusman, M., Dose: dependeni reduction by Nalox one of analgesia incuced by cold water stress, Pharmac. Biochem. Behav., 8 (1978)667-672.

4 Hayes, R.C., Bennett, G.J., Newlon, L.G. and Mayer, D.J., Behavisral and physirslogical studies of non-narcotic analgesia in the rat elicited by certain environmental stimul. Brain Ree., 155 115. $0,69-90$. 
5 'se, H.K., Chai, C.Y., Wayner, MJ., Koo, L.C. and Chung, P.M. Mesencephalí ecatrel pay locus of morphine and electrical stimulation induced till ereetion, Fharmecol Bioctran. Behur., 8 (1978) $221-226$.

6 Breurex, H., Bddy, N.B. and Bunwalt, M., The Prarmacology of the Opinm Alkeloida, Fahington D.C., U.8. Government Printing Office, 1941, pp. 1-20.

7 Siepd, S., Non Puametric Statictics for the Behrvional Sciences, McGraw-Hin, New York, 1856, $312 \mathrm{pp}$. 